\title{
Effect of Nitrogen Levels and Number of Irrigation on Growth and Yield of Wheat
}

\author{
Hemant Kumar Gangwar* and M.D. Lodhi
}

Brahmanand Post Graduate College, Rath, U.P., India

*Corresponding author

\begin{tabular}{l} 
K e y w o r d s \\
$\begin{array}{l}\text { DAS, Dry weight, } \\
\text { Growth, Irrigation, } \\
\text { Nitrogen level }\end{array}$ \\
\hline Article Info \\
$\begin{array}{l}\text { Accepted: } \\
\text { 28 February } 2018 \\
\text { Available Online: } \\
10 \text { March } 2018\end{array}$ \\
\hline
\end{tabular}

A B S T R A C T

A field experiment was carried out to evaluate the effect of nitrogen levels and irrigation on the growth and yield of wheat (Treaticum aestivum L. emend fiory and Paol) var.WH-331 in the Bundelkhand region of U.P. The experiment includes two factors such as four irrigation regimes and four nitrogen levels. The treatments were compared under the factorial R.B.D. with three replications. The soil of the experimental field was 'paruwa' (silty loam) according to the type of Bundelkhand soil having soil $\mathrm{pH}$ (7.6) low in available nitrogen and organic carbon; medium in available phosphorus and high in available potassium. Yield and yield contributing factors were significantly affected by different doses of nitrogen and irrigation regimes.120:60:60 kg NPK/ha application and fourth irrigation have found most suitable and economic combination for wheat crop under the existing conditions of Bundelkhand region in U.P.

\section{Introduction}

Wheat is a grass widely cultivated for its seed, a cereal grain which is a worldwide staple food (Belderok et al., 2000). There are many species of wheat which together make up the genus Triticum, the most widely grown is common wheat (T. aestivum). Wheat is grown on more land area than any other food crop (220.4 million hectares, 2014) (FAOSTAT, 2014). World trade in wheat is greater than for all other crops combined (Curtis et al., 2002). In 2016, world production of wheat was 749 million tonnes (FAO, 2016). Making it the second most produced cereal after maize (FAO, 2016). Since 1960, world production of wheat and other grain crops has tripled and is expected to grow further through the middle of the $21 \mathrm{st}$ century (Godfray et al., 2010).Globally, it is the leading source of vegetal protein in human food, having a protein content of about $13 \%$, which is relatively high compared to other major cereals, but relatively low in protein quality for supplying essential amino acids. When eaten as the whole grain, wheat is a source of multiple nutrients and dietary fiber (Shewry and Hey 2015).Wheat (Triticum aestivum L.) 
is one of the most important cereal crops in India, playing a dominant role in maintaining food security and farmer's income. Irrigation is a key measure in improving grain yield in wheat production, especially in arid and semiarid areas. With an increase in irrigation level, wheat grain yield is significantly improved (Sissons, et al., 2014). Irrigation at critical stages of wheat growth such as early tillering, jointing, heading and flowering was found to result in higher grain yield through an increase in spike number, fertile florets and heavier single grain weight (Rajala et al., 2009; Qui et al., 2008).

\section{Materials and Methods}

\section{Field preparation}

The first plugging was done by soil turning plough in workable condition of the field further plugging were done deshi plough fallowed by two harrowing and planking timely primary tillage practices were done properly to make the soil firm and friable ensuring proper germination of seeds.

\section{Seed Sowing}

WH-331 variety was chosen for sowing of experiment and $80 \mathrm{~kg} / \mathrm{ha}$ seed was kept. Seed sown after treating with agroson G.N. @ $49 / \mathrm{kg}$ seed.

\section{Weeding}

The process of weeding was done after 30 days of sowing. The type of plant and all common weeds were uprooted through manually.

\section{Irrigation}

The irrigation done according to the treatments i.e. zero, two, three and four irrigation. Among with $1^{\text {st }}$ was applied number irrigation, $2^{\text {nd }}$ irrigation was applied $21^{\text {st }}, 45^{\text {th }}$, and $3^{\text {rd }}$ irrigation was applied $21^{\text {st }} 45^{\text {th }}$ and $65^{\text {th }}$ DAS and fourth irrigation applied $21^{\text {st }}, 45^{\text {th }}$, $65^{\text {th }}, 85^{\text {th }}$ DAS.

\section{Height of main shoot $(\mathrm{cm})$}

30, 6090 DAS at harvest stage: five mature shoots were labeled separately and height was measured from ground level to of top most shoots mean was calculated.

\section{Number of functional leaves/plant}

Green leaves of leveled plants were united and further mean was calculated.

\section{Fresh weight/plant (g)}

Five plants from next to border second line from outer side were cut from ground level and weight average was worked out.

\section{Dry weight/plant (g)}

The above sample was kept in oven for 48 hours at 65.6 and weight till the constant weight is obtained. Jointly for the calculation of average dry weight per plant and them dry matter accumulation was calculated.

Number tiller/plant: From 5 selected plants number of tiller/plant were counted and average tillers / plant were worked out.

Length of ear $(\mathrm{cm})$ : At harvest: 5 ears from selected plant were measured and average was worked out.

Weight of ears (g): Five ears from selected plant were measured and average was worked out.

Number of fertile spikelet /ear: Five ears from selected plant were measured and average was worked out. 
Number grains /ear: Five ears from selected plant were measured and average was worked out.

Weight of grains/ears (g): Five ears from selected plant were measured and average was worked out.

Grain yield/plant: Five ears from selected plant were measured and average was worked out.

1000 seed weight $(\mathrm{g})$ : 1000 grain were counted farm the net plot yield and weighted.

Total produce $(\mathrm{q} / \mathrm{ha})$ : Calculated on the bases of net plot yield.

Grain yield ( $\mathrm{q} / \mathrm{ha})$ : calculated on the bases of net plot yield.

Straw yield $(\mathrm{q} / \mathrm{ha})$ : calculated on the bases of net plot yield.

Harvest-index (\%): grain yield (q/ha)/total produce $\mathrm{x} 100$.

\section{Statistical analysis}

All the growth, yield data were studied and analyzed statistically by Gomez and Gomez (1984).

\section{Results and Discussion}

\section{Effect of nitrogen levels}

Effect of growth phenology-The data presented in table (1 to 7) showed that all the biometric expressions were influenced by different nitrogen levels, the examination of the crop in terms of height of main shoot $(\mathrm{cm})$, number of functional leaves/plant, fresh and dry weight/plant $(\mathrm{g})$, number of tillers/plant and number of shoots/running meter were noted maximum in $120 \mathrm{~kg}$ (N3) nitrogen levels followed by $80 \mathrm{~kg}$ (N2), $40 \mathrm{~kg}$ (N1) and Control (N0). Nitrogen levels respectively the maximum growth and development under respective nitrogen levels is due to more utilization of plant nutrients. Table indicates that $120 \mathrm{~kg}$ nitrogen level increased significantly, maximum and 17.12, 33.42 and 61.22 percent more dry matter accumulation/plant $(\mathrm{g})$ over ther nitrogen levels such as $80 \mathrm{~kg}(\mathrm{~N} 2), 40 \mathrm{~kg}$ (N1) and control (N0) respectively. The maximum dry matter accumulation/plant is the resultant of increased height of main shoot, fresh weight /plant and number of tillers/plant. The above growth characters cause to increase dry matter production/plant. The Yadav and Lodhi (2001), Gupta et al., (2009) Chamani et al., (2010) were also reported that nitrogen nutrient increased weight, dry weight and number of tillers/plant.

\section{Effect on yield attributes and yield}

Differential response of nitrogen levels were observed in respect to yield attributes and yield reference to (table 1-7), it is clean that seed yield ( $q / \mathrm{ha})$ was found significantly maximum in $120 \mathrm{~kg}$, nitrogen dose, the respective nitrogen dose increased 17.12, 33.42 , 61.22 percent additional grain yield (q/ha) over $80 \mathrm{~kg}(\mathrm{~N} 2), 40 \mathrm{~kg}(\mathrm{~N} 1)$ and control (N0) respectively. The more production of seed yield is the resultant of number of shoot /unit area, number of tillers/plant, weight of grains and their yield attributes, the superior examination of the table indicate that yield contributing characters such as number of ears/plant, weight of ears/ plant (g) length of ear $(\mathrm{cm})$ number of fertile spikelets/ear, number of grains /ear, weight of grains/ear $(\mathrm{g})$, weight of grains /plant $(\mathrm{g})$ and weight of 1000 seeds (g) were recorded maximum in $120 \mathrm{~kg}$ nitrogen dose over other doses of nitrogen. It is mainly due to sufficient supply of nitrogen nutrient for the development of plant growth which promotes for increasing per plant grain 
weight and their characters. The results were conformity with the finding of Kumar and Singh (1999), Yadav and Lodhi (2001), Chamani and Mahmoodi (2010).

\section{Effect of number of irrigation}

Effect on growth phenology-Reference to table (1 to 7) clearly showed that different number of irrigation were increased growth of the plant the growth characters such as height of main shoot $(\mathrm{cm})$ number of functional leaves/plant fresh and dry weight/ plant $(\mathrm{g})$, number of tiller/plant and number of shoots/unit area were recorded maximum in irrigation. I3 (four irrigation $\mathrm{I}^{\text {st }}$ at 21 DAS + $\mathrm{II}^{\text {nd }}$ at $45 \mathrm{DAS}+\mathrm{III}^{\text {rd }}$ at $65 \mathrm{DAS}+\mathrm{IV}^{\text {th }}$ at 85 DAS) followed by other number of irrigation. The maximum dry matter production/plant (g) is the resultant of more growth of the plant the above all growth characters were recorded maximum in I3 (four irrigations $\mathrm{I}^{\text {st }}$ at 21 DAS $+\mathrm{II}^{\text {nd }}$ at $45 \mathrm{DAS}+\mathrm{III}^{\mathrm{rd}}$ at $65 \mathrm{DAS}+\mathrm{IV}^{\text {th }}$ at 85 DAS) number of irrigation which pushed and enhanced for increase dry matter production/plant $(\mathrm{g})$ the more growth in I4 (four irrigation $21 \mathrm{DAS}+\mathrm{II}^{\text {nd }}$ at $45 \mathrm{DAS}+$ $\mathrm{III}^{\text {rd }}$ at $65 \mathrm{DAS}+\mathrm{IV}^{\text {th }}$ at $\left.85 \mathrm{DAS}\right)$ Number of irrigation is due to the proper supply of irrigation during growth and development period of plant, Guler (2010) also reported that four equal number of irrigation increased more growth of the plant.

\section{Effect on yield attributes and yield}

It has been observed in table 1 to 7 that yield contributing characters such as number of ears/plant, weight of ears/plant (g), length of ear $(\mathrm{cm})$, number of fertile spikelets/ear, number of grains/ear, weight of grains/ear, weight of grains/plant (g). weight of 1000 grains (g) were recorded significantly maximum in $\mathrm{I} 3\left(21 \mathrm{DAS}+\mathrm{II}^{\text {nd }}\right.$ at $45 \mathrm{DAS}+$ $\mathrm{III}^{\text {rd }}$ at $65 \mathrm{DAS}+\mathrm{IV}^{\text {th }}$ at $\left.85 \mathrm{DAS}\right)$ number of irrigation over $\mathrm{I} 2$ (three irrigation $\mathrm{I}^{\text {st }}$ at 21
$\mathrm{DAS}+\mathrm{II}^{\text {nd }} 45 \mathrm{DAS}+\mathrm{III}^{\text {rd }}$ at $\left.65 \mathrm{DAS}\right)$ and I1 (two irrigation $\mathrm{I}^{\text {st }}$ at $21 \mathrm{DAS}+\mathrm{II}^{\mathrm{nd}}$ at $45 \mathrm{DAS}$ ) and I0 (no irrigation) number of irrigation respectively in respect to grain yield $\mathrm{q} / \mathrm{ha}$ the number of irrigation I3 (Four irrigation $\mathrm{I}^{\text {st }}$ at $21 \mathrm{DAS}+\mathrm{II}^{\mathrm{nd}}$ at $45 \mathrm{DAS}+\mathrm{III}^{\text {rd }}$ at $65 \mathrm{DAS}+$ $\mathrm{IV}^{\text {th }}$ at 85 DAS) was also increased significantly maximum value over other irrigation the respective number of irrigation. $4.38,15.22$ and 27.28 percent additional seed yield ( $\mathrm{q} / \mathrm{ha}$ ) over other number of irrigation such as I2 (three irrigation $\mathrm{I}^{\text {st }}$ at $21 \mathrm{DAS}+\mathrm{II}^{\text {nd }}$ at $45 \mathrm{DAS}+\mathrm{III}^{\mathrm{rd}}$ at $65 \mathrm{DAS}$ ), I1 (two irrigation $\mathrm{I}^{\text {st }}$ at $21 \mathrm{DAS}+\mathrm{II}^{\text {nd }}$ at $\left.45 \mathrm{DAS}\right)$ and IO (no irrigation) number of irrigation, respectively.

The grain yield /plant is the resultant of all the resultant of all the yield contributing characters while the grain yield $(\mathrm{q} / \mathrm{ha})$ is the opposite response of number of plants per unit area, grain weight plant ${ }^{-1}$ and per plant yield attributes. The above yield attributes such as number of ears/plant weight of ears/plant (g) length of ear $(\mathrm{cm})$ number of fertile spikelets/ear, number of grains/ear, weight of grains/ear, weight of grains/plant $(\mathrm{g})$ and weight of 1000 grains were recorded significantly maximum in (I3 four irrigation $\mathrm{I}^{\text {st }}$ at $21 \mathrm{DAS}+\mathrm{II}^{\mathrm{nd}}$ at $45 \mathrm{DAS}+\mathrm{III}^{\mathrm{rd}}$ at $65 \mathrm{DAS}$ $+\mathrm{IV}^{\text {th }}$ at 85 DAS) number of irrigations. Weight of grains per plant and their attributes were pushed and enhanced for increasing grains yield in $(\mathrm{q} / \mathrm{ha})$. The same results were also reported by Guler (2010).

\section{Interactions effect of nitrogen levels and number of irrigation}

It is evident from table 1 to 7 revealed that nitrogen level $120 \mathrm{~kg}$ (N3) and number of irrigation $\mathrm{I} 3$ (four irrigation $\mathrm{I}^{\mathrm{st}}$ at $21 \mathrm{DAS}+$ $\mathrm{II}^{\text {nd }}$ at $45 \mathrm{DAS}+\mathrm{III}^{\text {rd }}$ at $65 \mathrm{DAS}+\mathrm{IV}^{\text {th }}$ at 85 DAS) improved all the growth and yield contributing characters followed by other nitrogen levels and number of irrigations. 
Table.1 Height of main shoot $(\mathrm{cm})$ at successive stages of crop growth as influenced by different treatments

\begin{tabular}{|c|c|c|c|c|}
\hline \multirow[t]{2}{*}{ Treatments } & \multicolumn{3}{|c|}{ Days after sowing } & \multirow[t]{2}{*}{ At harvest } \\
\hline & 30 & 60 & 90 & \\
\hline \multicolumn{5}{|l|}{ Nitrogen levels kg/ha } \\
\hline N0 (control) & 13.00 & 48.52 & 62.83 & 67.66 \\
\hline $\mathrm{N} 1(40 \mathrm{~kg})$ & 14.00 & 51.44 & 68.83 & 74.41 \\
\hline $\mathrm{N} 2(80 \mathrm{~kg})$ & 16.02 & 54.10 & 75.08 & 82.83 \\
\hline N3(120 kg) & 17.02 & 56.63 & 78.16 & 93.00 \\
\hline $\mathrm{SE} \pm$ & 00.02 & 00.36 & 00.11 & 00.11 \\
\hline C.D. at $5 \%$ & 00.04 & 00.74 & 00.23 & 00.23 \\
\hline \multicolumn{5}{|l|}{ Number of irrigation } \\
\hline $\mathrm{I0}$ & 20.00 & 66.74 & 78.77 & 95.33 \\
\hline I1(21+45 day $)$ & 20.00 & 70.66 & 90.00 & 99.55 \\
\hline $\mathrm{I} 2(21+45+65)$ & 20.00 & 71.70 & 101.66 & 110.77 \\
\hline I3 $(21+45+65+85$ day $)$ & 20.07 & 71.84 & 109.44 & 118.22 \\
\hline $\mathrm{SE} \pm$ & 00.02 & 00.36 & 00.11 & 00.11 \\
\hline C.D. at $\mathbf{5 \%}$ & N.S. & 00.74 & 00.23 & 00.23 \\
\hline
\end{tabular}

Table.2 Number of functional leaves /plant at different stage of growth as influenced by different treatments

\begin{tabular}{|c|c|c|c|}
\hline \multirow[t]{2}{*}{ Treatments } & \multicolumn{3}{|c|}{ Days after sowing } \\
\hline & 30 & 60 & 90 \\
\hline \multicolumn{4}{|l|}{ Nitrogen levels kg/ha } \\
\hline N0 (control) & 8.50 & 16.91 & 20.25 \\
\hline N1(40 kg) & 8.16 & 18.75 & 21.50 \\
\hline N2(80 kg) & 11.25 & 21.41 & 21.91 \\
\hline N3 (120 kg) & 13.41 & 23.08 & 23.41 \\
\hline S.Ed \pm & 00.46 & 00.31 & 00.27 \\
\hline C.D.at 5\% & 00.95 & 00.63 & 00.57 \\
\hline \multicolumn{4}{|l|}{ Number of irrigation } \\
\hline I0 (0) & 12.66 & 24.55 & 27.22 \\
\hline I1(21+45 day) & 13.55 & 26.33 & 28.11 \\
\hline $\mathrm{I2}(21+45+65$ day $)$ & 14.22 & 27.88 & 29.77 \\
\hline $\mathrm{I3}(21+45+65+85$ day $)$ & 16.66 & 28.11 & 31.00 \\
\hline S.Ed \pm & 00.46 & 00.31 & 00.27 \\
\hline C.D at $5 \%$ & N.S. & 00.63 & 00.57 \\
\hline
\end{tabular}


Table.3 Fresh weight per plant (g) at different stages of growth as influenced by different treatments

\begin{tabular}{|c|c|c|c|}
\hline \multirow[t]{2}{*}{ Treatments } & \multicolumn{3}{|c|}{ Days after sowing } \\
\hline & 30 & 60 & 90 \\
\hline \multicolumn{4}{|l|}{ Nitrogen levels kg/ha } \\
\hline N0 (control) & 6.36 & 21.80 & 45.93 \\
\hline $\mathrm{N1}(40 \mathrm{~kg})$ & 6.63 & 21.98 & 47.34 \\
\hline N2(80 kg) & 6.73 & 22.88 & 47.41 \\
\hline N3 (120 kg) & 6.81 & 23.10 & 47.51 \\
\hline S.Ed \pm & 0.14 & 00.43 & 00.29 \\
\hline C.D.at 5\% & N.S. & 00.88 & 00.60 \\
\hline \multicolumn{4}{|l|}{ Number of irrigation } \\
\hline I0 (0) & 8.82 & 29.00 & 61.66 \\
\hline I1(21+45 day) & 8.80 & 30.33 & 62.66 \\
\hline $\mathrm{I} 2(21+45+65$ day $)$ & 8.86 & 30.33 & 63.06 \\
\hline $\mathrm{I} 3(21+45+65+85$ day $)$ & 8.91 & 30.02 & 63.54 \\
\hline S.Ed \pm & 0.14 & 00.43 & 00.29 \\
\hline C.D at $5 \%$ & N.S. & N.S. & 00.60 \\
\hline
\end{tabular}

Table.4 Dry weight/plant (g) at different stages of growth as influenced by different treatments

\begin{tabular}{|l|c|c|c|}
\hline \multirow{2}{*}{ Treatments } & Days after sowing & & \\
\hline Nitrogen levels kg/ha & 30 & 60 & \\
\hline N0 (control) & & & 14.83 \\
\hline N1(40 kg) & 1.32 & 8.46 & 15.11 \\
\hline N2(80 kg) & 1.39 & 8.47 & 15.16 \\
\hline N3 (120 kg) & 1.50 & 4.48 & 15.57 \\
\hline S.Ed & 1.50 & 8.69 & 00.13 \\
\hline C.D.at 5\% & 0.07 & 0.07 & 00.27 \\
\hline Number of irrigation19.66 & N.S. & 0.14 & \\
\hline I0 (0) & 1.97 & 11.27 & 19.66 \\
\hline I1(21+45 day) & 1.86 & 11.28 & 20.17 \\
\hline I2(21+45+65 day) & 1.91 & 11.44 & 20.43 \\
\hline I3(21+45+65+85 day) & 1.87 & 11.47 & 20.64 \\
\hline S.Ed \pm & 0.07 & 00.07 & 00.13 \\
\hline C.D at 5\% & N.S. & N.S. & 00.27 \\
\hline
\end{tabular}


Table.5 Plant population/unit area as influenced by different treatments

\begin{tabular}{|l|c|c|}
\hline Treatments & Number of tillers/plant & $\begin{array}{c}\text { Number of shoots/running } \\
\text { meter }\end{array}$ \\
\hline Nitrogen levels kg/ha & & \\
\hline No (control) & 2.08 & 19.94 \\
\hline N1(40 kg) & 3.22 & 20.00 \\
\hline N2(80 kg) & 3.57 & 20.00 \\
\hline N3(120 kg) & 3.83 & 20.05 \\
\hline S.Ed \pm & 0.05 & 00.03 \\
\hline C.D. at 5\% & 0.10 & N.S. \\
\hline Number of irrigation & & 26.62 \\
\hline I0 (0) & 3.99 & 26.66 \\
\hline I1(21+45 day) & 4.21 & 26.66 \\
\hline I2(21+45+65 day) & 4.39 & 26.70 \\
\hline I3(21+45+65+85 day) & 4.35 & 00.03 \\
\hline S.Ed \pm & 0.05 & N.S. \\
\hline C.D at 5\% & 0.10 & \\
\hline
\end{tabular}

Table.6 Grain weight per plant and their attributes as influenced by different treatments

\begin{tabular}{|c|c|c|c|c|c|c|c|c|}
\hline Treatments & $\begin{array}{c}\text { Number } \\
\text { of ears } \\
\text { per } \\
\text { running } \\
\text { meter }\end{array}$ & $\begin{array}{l}\text { Length } \\
\text { of ears } \\
\text { in }(\mathrm{cm})\end{array}$ & $\begin{array}{l}\text { Number } \\
\text { of fertile } \\
\text { spikelets }\end{array}$ & $\begin{array}{l}\text { Number } \\
\text { of sterite } \\
\text { spikelets }\end{array}$ & $\begin{array}{c}\text { Number } \\
\text { of grain } \\
\text { per plant }\end{array}$ & $\begin{array}{c}\text { Weight } \\
\text { of } \\
\text { grains } \\
\text { per ears }\end{array}$ & $\begin{array}{c}\text { Number of } \\
\text { grain per } \\
\text { ears }\end{array}$ & $\begin{array}{c}\text { Test } \\
\text { weight } \\
(1000) \\
\text { grains }\end{array}$ \\
\hline \multicolumn{9}{|c|}{ Nitrogen levels $\mathrm{kg} / \mathrm{ha}$} \\
\hline N0 (control) & 39.16 & 06.13 & 14.94 & 4.00 & 30.77 & 01.97 & 57.66 & 34.08 \\
\hline N1(40 kg) & 63.66 & 07.97 & 15.22 & 3.19 & 31.36 & 03.39 & 99.25 & 34.16 \\
\hline N2 $(80 \mathrm{~kg})$ & 70.58 & 08.35 & 15.44 & 1.91 & 31.69 & 03.77 & 110.16 & 34.16 \\
\hline N3(120kg) & 73.50 & 08.99 & 16.47 & 1.88 & 34.77 & 04.22 & 120.91 & 34.16 \\
\hline S.Em \pm & 00.85 & 00.05 & 00.15 & 0.09 & 0.03 & 00.00 & 00.02 & 00.02 \\
\hline C.D.at 5\% & 01.73 & 00.10 & 00.32 & 0.18 & 0.06 & 00.01 & 00.05 & 00.05 \\
\hline \multicolumn{9}{|c|}{ Number of irrigation } \\
\hline $\mathrm{I0}(0)$ & 76.33 & 10.18 & 20.03 & 4.03 & 41.48 & 03.94 & 115.88 & 45.33 \\
\hline I1(21+45 day) & 82.77 & 10.44 & 20.70 & 3.74 & 43.03 & 04.33 & 126.66 & 45.44 \\
\hline $\begin{array}{l}\mathrm{I} 2(21+45+65 \\
\text { day })\end{array}$ & 83.33 & 10.48 & 20.92 & 3.44 & 43.77 & 04.66 & 134.99 & 45.74 \\
\hline $\begin{array}{l}\mathrm{I} 3(21+45+65+8 \\
5 \text { day })\end{array}$ & 86.77 & 10.84 & 21.10 & 3.44 & 43.18 & 04.87 & 139.77 & 46.24 \\
\hline S.Em & 00.85 & 0.05 & 00.15 & 0.09 & 0.03 & 00.01 & 0.02 & 00.02 \\
\hline C.D at $5 \%$ & 01.73 & 0.10 & 00.32 & 0.18 & 0.06 & 00.01 & 0.05 & 00.05 \\
\hline
\end{tabular}


Table.7 Yield /unit area as affected by different treatments

\begin{tabular}{|c|c|c|c|c|}
\hline Treatments & $\begin{array}{l}\text { Total Produce } \\
\text { (q/ha) }\end{array}$ & $\begin{array}{l}\text { Grain yield } \\
\text { (q/ha) }\end{array}$ & $\begin{array}{l}\text { Straw yield } \\
\text { (q/ha) }\end{array}$ & $\begin{array}{c}\text { Harvest index } \\
(\%)\end{array}$ \\
\hline \multicolumn{5}{|l|}{ Nitrogen levels kg/ha } \\
\hline No (control) & 17.15 & 17.16 & 34.32 & 49.98 \\
\hline N1(40 kg) & 29.30 & 29.46 & 58.76 & 49.86 \\
\hline N2(80 kg) & 32.64 & 36.67 & 69.31 & 47.27 \\
\hline N3(120 kg) & 36.80 & 44.25 & 81.05 & 45.58 \\
\hline S.Ed \pm & 00.03 & 00.03 & 00.05 & 00.02 \\
\hline C.D. at 5\% & 00.06 & 00.06 & 00.11 & 00.05 \\
\hline \multicolumn{5}{|l|}{ Number of irrigation } \\
\hline $\mathrm{I0}(0)$ & 34.05 & 35.02 & 69.07 & 65.90 \\
\hline I1(21+45 day) & 37.44 & 40.83 & 78.27 & 64.36 \\
\hline $12(21+45+65$ day $)$ & 40.52 & 46.05 & 86.57 & 63.33 \\
\hline $\mathrm{I}(21+45+65+85$ day $)$ & 42.51 & 48.16 & 90.67 & 63.36 \\
\hline S.Ed \pm & 00.03 & 00.03 & 00.05 & 00.02 \\
\hline C.D.at 5\% & 00.06 & 00.06 & 00.11 & 00.05 \\
\hline
\end{tabular}

Table.8 Effect of different treatments on cost of cultivation (Rs/ha) gross income (Rs/ha) net income (Rs/ha and $\mathrm{B} / \mathrm{C}$ ratio)

\begin{tabular}{|l|c|c|c|c|}
\hline Treatments & $\begin{array}{c}\text { Total cost of } \\
\text { cultivation (Rs/ha) }\end{array}$ & $\begin{array}{c}\text { Total gross } \\
\text { return (Rs/ha) }\end{array}$ & $\begin{array}{c}\text { Total net return } \\
\text { (Rs/ha) }\end{array}$ & B/C ratio \\
\hline Nitrogen levels kg/ha & 19644.9 & 43629.12 & 23984.22 & 1.23 \\
\hline N0 (control) & 20955.7 & 46564.375 & 25609.00 & 1.23 \\
\hline N1 (40 kg) & 22422.52 & 52707.07 & 30284.5 & 1.35 \\
\hline N2 (80 kg) & 23887.95 & 58402.15 & 34514.2 & 1.45 \\
\hline N3 (120 kg) & 1888.4 & 46862.0 & 27977.6 & 1.48 \\
\hline Irrigation & 21468.35 & 50486.65 & 29018.3 & 1.34 \\
\hline I0 (0) & 22487.62 & 49067.4 & 26579.78 & 1.17 \\
\hline I1 (two) & 24070.75 & 54887.5 & 30816.3 & 1.26 \\
\hline I2 (three) & & &
\end{tabular}

The improvement of growth and yield contributing characters were due to separate superior improvement of respective nitrogen levels of irrigations. In respect of biomass production, grain yield and straw yield production in $\mathrm{q} / \mathrm{ha}$ were recorded significantly maximum in $120 \mathrm{~kg}$ nitrogen level and $\mathrm{I} 3$ (four irrigation $\mathrm{I}^{\mathrm{st}}$ at 21 DAS $+\mathrm{II}^{\text {nd }}$ at 45 $\mathrm{DAS}+\mathrm{III}^{\mathrm{rd}}$ at $65 \mathrm{DAS}+\mathrm{IV}^{\text {th }}$ at $\left.85 \mathrm{DAS}\right)$ number of irrigation over other nitrogen level and number of irrigation to sufficient amount and proper availability of nitrogen nutrient during growth and development period of crop.

The results were conformity with findings of Gupta et al., (2009) and Chamani et al., (2010). 


\section{Effect of economics}

To judge the best combination of input for getting maximum output in farming business have great in have great importance in this connections the economics was calculated and presented. In table - and showed that maximum net return Rs.34514.2/ha and Rs 30816.3/ha was calculated in $120 \mathrm{~kg}$ nitrogen level and I3 (four irrigation It at $21 \mathrm{DAS}+$ $\mathrm{II}^{\text {nd }}$ at $45 \mathrm{DAS}+\mathrm{III}^{\text {rd }}$ at $65 \mathrm{DAS}+\mathrm{IV}^{\text {th }}$ at 85 DAS) number of irrigation treatments respectively. The combined effect of respective nitrogen level and number of irrigation $120 \mathrm{~kg} \mathrm{~N}$ and $\mathrm{I}^{\mathrm{st}}$ at $21 \mathrm{DAS}+\mathrm{II}^{\mathrm{nd}}$ at $45 \mathrm{DAS}+\mathrm{III}^{\mathrm{rd}}$ at $65 \mathrm{DAS}+\mathrm{IV}^{\text {th }}$ at $85 \mathrm{DAS}$ was also computed maximum net return RS 34514.2/ ha Rs. 30816.3/ha over other nitrogen and irrigation doses and nitrogen form the net return (RS/ha) base, the nitrogen level $120 \mathrm{~kg}$ and irrigation I3 (four irrigation $\mathrm{I}^{\text {st }}$ at $21 \mathrm{DAS}+\mathrm{II}^{\text {nd }}$ at $45 \mathrm{DAS}+\mathrm{III}^{\mathrm{rd}}$ at 65 DAS+ IV ${ }^{\text {th }}$ at 85 DAS) of nitrogen application is the economics combination for wheat crop. It is mostly due to superior grain yield ( $/ \mathrm{ha}$ ) recorded under the respective nitrogen level and number of irrigations.

\section{Effect of nitrogen levels}

The growth characters such as height of main shoot $(93.00 \mathrm{~cm})$, Number of functional leaves/plant (23.41), fresh weight/plant (47.51 g) and dry weight/plant $(15.57 \mathrm{~g})$ were recorded maximum in nitrogen level $120 \mathrm{~kg}$ (N3) followed by $80 \mathrm{~kg}(\mathrm{~N} 2), 40 \mathrm{~kg}(\mathrm{~N} 1)$ and control (N0) nitrogen levels respectively. The number of tillers/plant (3.83) and number of shoots/running meter (73.50) were counted significantly more in $120 \mathrm{~kg}$ (N3) nitrogen level over other nitrogen levels. The yield contributing characters such as number of ears/plant (20.05), weight of ears/plant (8.10 $\mathrm{g})$, length of ear $(8.99 \mathrm{~cm})$, number of fertile spikelets) ear (16.67), weight of grain/ear (4.22 g) number of grains/ear (120.91), weight of grains/plant (4022 g) were recorded significantly maximum in $120 \mathrm{~kg}(\mathrm{~N} 3)$ nitrogen level followed by other nitrogen levels such as $80 \mathrm{~kg}(\mathrm{~N} 2), 40 \mathrm{~kg}(\mathrm{~N} 1)$ and Control (N0) respectively. The total produce (36.80 q/ha) and straw yield (81.05 q/ha) were recorded significantly maximum nitrogen level $120 \mathrm{~kg}(\mathrm{~N} 3)$ followed by $80 \mathrm{~kg}(\mathrm{~N} 2)$, $40 \mathrm{~kg}$ (N1) and control (N0) respectively. The grain yield (44.25) was recorded significantly maximum and 17.12, 33.42 and 61.22 percent more in nitrogen level $120 \mathrm{~kg}$ (N3) followed by $80 \mathrm{~kg}(\mathrm{~N} 2), \mathrm{N} 0 \mathrm{~kg}(\mathrm{~N} 1)$ and control (N0) respectively. The harvest index (45.58) was computed significantly more in $120 \mathrm{~kg}$ (N3) nitrogen level followed by other nitrogen levels with the minimum value $\mathrm{N} 2(40 \mathrm{~kg})$ nitrogen dose. The maximum net income Rs34514.2/ha was calculated in $120 \mathrm{~kg}(\mathrm{~N} 3)$ nitrogen level which was Rs 4229.7, Rs 8905.2 and Rs.10529.98/ha as additional value over $80 \mathrm{~kg}(\mathrm{~N} 2), 40 \mathrm{~kg}(\mathrm{~N} 1)$ and control (N0) nitrogen levels respectively.

\section{Effect on number of irrigation}

The growth characters such as height of main shoot $(118.22 \mathrm{~cm})$ number of functional leaves/plant 931.00) fresh weight/plant (6354 g) on dry weight/plant $(20.64$ g) were recorded significantly maximum in I3 (Fourth) irrigation over other number of irrigation. Number of tillers/plant (4.35) and total number of shoots per running meter (86.77) was recorded more in I3 (fourth) irrigation over other number of irrigation. The yield contributing characters such as number of ears/plant (26.70) weight of ears/plant $(7.75 \mathrm{~g})$ length of ear $(10.84 \mathrm{~cm})$, number of fertile spikelets/ear (21.10) weight of ear $(4.87 \mathrm{~g})$, number of grains/plant $(4.87 \mathrm{~g})$ and weight of 1000 grains $(46.24 \mathrm{~g})$ were recorded significantly maximum in I3 (Fourth) irrigation over I2 (three) I0 (two) irrigation (I) (N0 irrigation) respectively. The total produce $(42.51 \mathrm{q} / \mathrm{ha})$ and straw yield 
(90.67 q/ha) were recorded significantly maximum in I3 (fourth) irrigation followed by other number of irrigation. Grain yield (48.16 $\mathrm{q} / \mathrm{ha}$ ) was recorded significantly maximum in I3 (fourth) irrigation which was 4.38, 15.22 and 27.28 percent more over I2 (three), I1 (two) and I0 (no irrigation) irrigation respectively. Harvest index (63.36\%) was calculated significantly more in 10 (no irrigation) over I3 (fourth) and I2 (three) irrigation respectively. The maximum net profit Rs 30816.3/ha was accrued in I3 (fourth) irrigation which was RS.4236.52/ha Rs.1798.0/ha and Rs 2338.7/ha as additional net income/ha over I1 (two, I2 (three) irrigation and 10 (No irrigation) respectively.

On the basis of results summarized above the main conclusions are drawn:- the 120:60:60 $\mathrm{kg} \mathrm{NPK} / \mathrm{ha}$ application was found most suitable for wheat crop. The fourth irrigation was found most suitable for wheat crop. 120:60:60 kg NPK/ha application and fourth irrigation have found most suitable and economic combination for wheat crop under the existing conditions of Bundelkhand region in U.P.

\section{References}

Belderok R B, Mesdag H, Donner D A. (2000). Bread-Making Quality of Wheat, Springer.

Chamani T, Mahmoodi S, Mohassel M H and Zamani G. (2010). Effect of nitrogen on vegetative growth parameters of wheat in competition with wild oat (Avena fatua) proceedings of $3^{\text {rd }}$ Iranian weed Science Congress, Vol.1:331-334.

Curtis R, MacPherson. (2002). Bread Wheat. Food and Agriculture Organization of the United Nations. (http://www.fao. org/docrep/006/y4011e/y4011e00.htm)

Godfray H C, Beddington J R, Crute I R, Haddad L, Lawrence D, Muir J F, Pretty J, Robinson S, Thomas S M, Toulmin
C. (2010). Food security: The challenge of feeding 9 billion people (http:// science.sciencemag.org/content/327/596 7/812.full). Science, 327 (5967): 812-8.

Gomez, K. A. and Gomez, A. A. (1984). Statistical procedure for agricultural research. John Wiley and Sons, New York, 139-153.

Guler M. (2010). The effect of different nitrogen and irrigation levels on grain beta-glucan content in some durum wheat cultivars. 2(10): 325-326.

Gupta A, Gupta M, Ball A S. (2009). Effect of different doses on duram wheat ( $T$. aestivum L.) cultivars under the subtropical condition of Jammu. Advances in plant sciences 22(2): 469470.

http://faostat.fao.org/site/567/DesktopDefault. aspx?P ageID $=567$ \#ancor

http://www.fao.org/worldfoodsituation/csdb/e $\mathrm{n}$

Kumar A and Singh V K. (1999). Effect of nitrogen levels and split application on growth and yield of wheat ( $T$. aestivum): Emend fiori and paol under the Bundelkhand conditions in UP, M. Sc. thesis agronomy, Bundelkhanf University. pp 64.

Qiu G Y, Wang L, He X, Zhang X, Chen S, Chen J. (2008). Water use efficiency and evapotranspiration of winter wheat and its response to irrigation regime in the north China plain. Agricultural and Forest Meteorology, 148: 1848-1859.

Rajala A, Hakala K, Makela P, Muurinen S, Peltonen S P. (2009). Spring wheat response to timing of water deficit through sink and grain filling capacity. Field Crops Research, 114: 263-271.

Shewry P R, Hey S J. (2015). Review: The contribution of wheat to human diet and health http://onlinelibrary.wiley.com/ doi/10.1002/fes3.64/pdf. Food and Energy Security, 4 (3): 178-202. 
Sissons M, Ovenden B, Adorada D, Milgate A. (2014). Durum wheat quality in high-input irrigation systems in southeastern Australia. Crop and Pasture Science, 65: 411-422.

Yadav A K and Lodhi M D. (2001). Studies on nitrogen levels and their split application on growth and yield of wheat (T. aestivum) var. K-9107 under the Bundelkhand M. Sc. thesis Agronomy, Bundelkhand University, Jhansi pp-70.

\section{How to cite this article:}

Hemant Kumar Gangwar and Lodhi, M.D. 2018. Effect of Nitrogen Levels and Number of Irrigation on Growth and Yield of Wheat. Int.J.Curr.Microbiol.App.Sci. 7(03): 3663-3673. doi: https://doi.org/10.20546/ijcmas.2018.703.424 